\title{
ВСЕСВITHЯ ІСТОРІЯ
}

Науковий вісник Чернівецького університету імені Юрія Федьковича: Історія. - № 2. - 2018. - С. 111-121. History Journal of Yuriy Fedkovych Chernivtsi National University. - № 2. - 2018. - pp. 111-121. DOI https://doi.org/10.31861/hj2018.48.111-121 hj.chnu.edu.ua

УДК 94 (470):323.283] «1911»

(C) Олександр Безаров ${ }^{1}$ (Чернівці)

\section{ДО ПИТАННЯ ПРО МОТИВИ ВБИВСТВА П. А. СТОЛИПІНА}

Проаналізовано мотиви замаху на життя голови Ради міністрів Російської імперії П. А. Столипіна 1 вересня 1911 р. у Києві, який скоїв колишній член київської організаиії анархістівкомуністів і таємний агент Київського охоронного відділення Департаменту полічії Д. Г. Богров. Визначено, що у мотивах убивства не останню роль відіграв фактор начіональності терориста. Типовий представник асимільованої російсько-сврейської інтелігениії Д. Г. Богров учинив публічне самогубство у вигляді замаху на життя відомого російського реформатора, яке стало для Д. Г. Богрова трагічним фіналом у його болісних прочесах пошуку шляхів подолання кризи ідентичності.

Ключові слова: Д. Г. Богров, П. А. Столипін, Київ, євреї, Російська імперія, тероризм, анархізм.

\section{Oleksandr Bezarov (Chernivtsi)}

\section{TO THE QUESTION ABOUT THE MOTIVES OF THE ASSASSINATION OF P. A. STOLYPIN}

Abstract. The assassination attempt on the life of P. A. Stolypin, the chairman of the Council of Ministers of the Russian Empire, on September 1, 1911 in Kyiv, made by D. G. Bogrov, a former member of the Kyivan organization of anarchists-communist and secret agent of the Kyiv Security Section of the Police Department, can be considered one of the most mysterious events in the history of late imperial Russia. Despite a large number of published archival documents on the history of this case, in modern historical science there is no unambiguous answer to the questions about the true motives that pushed D. $G$. Bogrov to commit this violent murder. According to the author, in the motives of the assassination of P. A. Stolypin by D. G. Bogrov, the factor of nationality of the terrorist played some role. D. G. Bogrov, a typical representative of the assimilated Russian-Jewish intellectuals did not become a convinced revolutionary; instead he lacked public recognition of his personal ambitions to satisfy which having the status of a Jewish citizen appeared to be not so simple. Public suicide in the form of an assassination attempt on the life of the famous Russian reformer became for D. G. Bogrov a tragic finale in his painful processes of finding ways to overcome the crisis of identity.

Keywords: D. G. Bogrov, P. A. Stolypin, Kyiv, Jews, Russian empire, terrorism, anarchism.

Постановка наукової проблеми та ії значення. У політичній історії Російської імперії знайдеться достатньо прикладів замахів на життя імператорів і міністрів, які й донині оповиті таємницею стосовно обставин і причин їх скоєння, але які у той чи інший спосіб визначали

1 к.і.н., доцент кафедри історії Нового та новітнього часу Чернівецького національного університету імені Юрія Федьковича.

PhD in History, Associate Professor, the Department of Modern and Contemporary History, Yuriy Fedkovych Chernivtsi National University.

orcid.org/0000-0002-8467-0647

E-mail alex.bezarov@gmail.com 
увесь наступний розвиток самодержавства, впливали на характер внутрішньої та зовнішньої політики імперії Романових. Проте у більшості з цих випадків мотиви вбивць державних діячів були очевидними, оскільки пов'язувалися 3 питаннями боротьби за владу поміж двірцевими угрупуваннями або були наслідками революційної діяльності терористичних груп і партій. Мабуть, що замах на життя голови Ради міністрів Російської імперії П. А. Столипіна 1 вересня 1911 р. у Києві, який скоїв колишній член київської організації анархістів-комуністів і таємний агент Київського охоронного відділення Департаменту поліції Д. Г. Богров, можна вважати однією із найзагадковіших подій в історії пізньоімперської Росії. Незважаючи на значну кількість опублікованих архівних документів з історії цієї справи, у сучасній історичній науці вочевидь немає однозначної відповіді на запитання з приводу справжніх мотивів, які штовхнули Д. Г. Богрова на скоєння цього зухвалого вбивства, яке, за своїми політичними наслідками, виявилося для самодержавства історичним, адже у певному сенсі прискорило його занепад.

Отже, завданням статті є аналіз відомих у сучасній історіографіїпідходів у дослідженні можливих мотивів убивства П. А. Столипіна - з метою формулювання власного припущення стосовно тих факторів, які виявилися ключовими в ухваленні рішення Д. Г. Богрова про скоєння замаху на життя П. А. Столипіна. Об'єктом дослідження є обставини справи про вбивство російського прем'єрміністра, а предметом - визначення вірогідних мотивів його вбивства.

Аналіз останніх досліджень. У сучасній історичній науці, як зазначав російський дослідник Г. П. Сидоровнін, конкурували щонайменше вісім версій з приводу визначення причини вбивства П. А. Столипіна ${ }^{1}$, 3-поміж яких, на нашу думку, лише декілька стосувалися безпосередньо мотивів його скоєння.

Зокрема, на думку сучасного українського історика В. П. Даниленка, існувала версія, що Богров здійснив цей теракт для того, щоб звільнити Росію від «міністра-вішальника». За офіційними даними - він терорист-одинак. За іншою версією, зазначав В. П. Даниленко, Богров видав охранці 150 революціонерів різних партій та програв у карти партійну касу, був викритий і замість помсти революціонерів вибрав смерть на шибениці як убивця Столипіна².

Сучасна російська дослідниця 3. І. Перегудова у своєму вступі до збірника архівних матеріалів зі «справи Столипіна-Богрова» ${ }^{3}$ спробувала узагальнити відомі в історіографії версії стосовно причин вбивства Столипіна та зробила висновок про те, що можна визнати лише дві з них, а саме: «Богров революціонер» $\mathrm{i}$ «Богров - змова» ${ }^{4} .3$ приводу другої версії 3. І. Перегудова справедливо зазначала, що вперше вона була запропонована відомим радянським істориком А. Я. Аврехом і поширена сучасними дослідниками, зокрема П. М. Зиряновим, котрий вважав, що вбивство Столипіна було ланкою в єдиному ланцюзі «змови» представників вищої царської адміністрації проти Столипіна 3 метою прибрати надто амбіційного прем'єр-міністра ${ }^{5}$. У цій «змові», на думку П. М. Зирянова, були задіяні товариш міністра внутрішніх справ П. Г. Курлов, віце-директор Департаменту поліції М. М. Верігін, начальник двірцевої охорони О. І. Спиридович і начальник Київського охоронного відділення М. М. Кулябко ${ }^{6}$. Отже, не варто було виключати тієї обставини, що Столипіна зазначена четвірка могла «ліквідувати» завдяки пострілу Богрова, якого, незабаром, поспіхом засудили до смертної кари та повісили. Проте, зауважував російський дослідник, жандармське начальство, мабуть, надто «загралося» із Богровим, який за бажання міг влучити й у царя7.

Теорію «змови» у справі вбивства Столипіна було підтримано українськими дослідниками Д. В. Табачником і В. М. Вороніним ${ }^{8}$, а також американським істориком і публіцистом С. С. Резніком9 .

Зокрема, автори фундаментального дослідження обставин життя і смерті відомого російського реформатора небезпідставно, з нашого погляду, висловили думку з приводу того, що політична кар'єра Столипіна на початку 1911 р. була приречена, а в його швидкоплинній відставці в офіційному Петербурзі вже мало хто сумнівався. Однак у спробах визначити місце та роль Богрова у планах «змовників», Д. В. Табачник і В. М. Воронін припустилися певної суперечності, коли, приміром, зазначали стосовно мотивів поведінки вбивці Столипіна про те, що «неможливо з позиції логіки та здорового глузду зрозуміти вчинок людини, котра немовби щойно зійшла зі сторінок одного 3 романів Достоєвського» ${ }^{10}$. Не уникнув надто умоглядних висновків й С. С. Резнік, який у своїх доволі розлогих критичних зауваженнях 3 приводу відомого твору російського письменника O. I. Солженіцина ${ }^{11}$ відводив Богрову роль безмотивного «провокатора» ${ }^{12}$ у підступних планах «петербурзьких заколотників» з ліквідації російського прем’єр-міністра у Києві. Отже, на думку 
С. С. Рєзніка, головним «змовником» у справі Столипіна виявився «коронований революціонер», останній російський імператор, котрий власноруч «рубав гілку, на якій сидів» ${ }^{13}$. Певної інтриги до теорії «змови» в історії замаху на Столипіна додавало свідчення Київського генерал-губернатора Ф. Ф. Трепова (мол.) з приводу того, що, мовляв, Богров у день замаху, начебто, обідав у ресторані «Метрополь» із Л. Д. Троцьким, яке навели у власному розслідуванні «справи Столипіна-Богрова» російські письменники Ю. С. Рибас і Л. В. Тараканова ${ }^{14}$.

На думку 3. І. Перегудової, вищезазначені конспірологічні теорії мало що можуть пояснити нам стосовно розуміння справжніх причин замаху на російського прем'єр-міністра ${ }^{15}$. Натомість вона висунула власну, більш реалістичну, як нам видається, гіпотезу, згідно 3 якою причиною вересневої трагедії була службова недбалість, самовпевненість, а почасти й політична ангажованість жандармського начальства у справі гарантування особистої безпеки упродовж перебування Столипіна у Києві ${ }^{16}$. 3. І. Перегудова небезпідставно вважала, що Богров був захоплений ідеєю вбивства навіть після того, як став агентом охранки, а його «душевна криза» стала тим останнім імпульсом, який, зрештою, призвів до «злочину століття» ${ }^{17}$.

Цікавими, на нашу думку, виглядають версії, що були сформульовані українськими дослідниками В. К. Волковинським ${ }^{18}$ і В. Любченком ${ }^{19}$. Зокрема, В. К. Волковинський припускав, що Богров узагалі «не думав» убивати Столипіна, проте замах на голову Ради міністрів був імітацією, аби він зміг потрапити до рук поліції й, у такий незвичний спосіб, уникнути помсти революціонерів, які його підозрювали у зрадництві ${ }^{20}$. Власне революція для Богрова, 3 точки зору В. К. Волковинського, уявлялася миттєвістю в його біографії, яка у жодному випадку не збігалася з його мріями стати відомим адвокатом ${ }^{21}$. В. Любченко, натомість, спробував проаналізувати мотивацію «Богроваєврея» у вбивстві Столипіна, але остаточного висновку він, мабуть, так і не дійшов, хоча й відкинув «необгрунтовані» припущення сучасної української дослідниці В. Хітерер про «єврейський чинник» у замаху Богрова 22.

У свою чергу, В. Хітерер висловила альтернативну думку з приводу відомих подій, які вона схильна була розглядати крізь призму пошуку крихкого політичного компромісу між російським урядом і лояльною частиною російського єврейства, що, з іï погляду, мав би розпочатися після офіційної зустрічі Миколи II з єврейської делегацією Києва 30 серпня 1911 р., але який було зірвано після пострілу Богрова. Зокрема, В. Хітерер зазначала, що «союз правлячих кіл із єврейським духовенством розпався із вбивством його ініціатора з боку уряду П. А. Столипіна... Це політичне вбивство здійснив єврейський революціонер Дмитро Григорович Богров... Наступні прем'єрміністри Російської імперії не поверталися вже до питання про співробітництво з єврейськими релігійними лідерами» ${ }^{23}$.

Отже, незважаючи на доволі змістовні дослідження, в яких фігурують різноманітні версії вересневих подій у Києві 1911 р., у сучасній історіографії, як справедливо зазначала 3. І. Перегудова, справжні причини вбивства Столипіна, натомість, залишаються незрозумілими ${ }^{24}$, а бурхливі дискусії 3 приводу особистості його вбивці не вщухають поміж дослідниками, мабуть, і донині.

Виклад основного матеріалу. Головною проблемою у спробах сучасних істориків визначити мотиви вбивства Столипіна була і залишається проблема належності Богрова до революційних організацій, його зв'язків із охранкою. 3'ясування фактичних обставин цієї проблеми виявилося не простим завданням. Наприклад, київський анархіст-комуніст Г. Б. Сандомирський спробував перекласти провину за вбивство Столипіна на генерала П. Г. Курлова, який відповідав за особисту безпеку Миколи II і російських урядовців під час їхнього перебування у Києві, з метою виправдати свого колишнього товариша в очах революціонерів, котрі підозрювали Богрова у зрадництві ${ }^{25}$. Проте, як відомо, такі підозри виявилися цілком обгрунтованими, адже сумнівів у тому, що Богров був «корисним інформатором» на службі у царської охранки, у сучасних дослідників, мабуть, уже немає. Натомість П. Г. Курлов, котрий, за версією Г. Б. Сандомирського, начебто прагнув «підставити» під це вбивство М. М. Кулябка та інших жандармських чиновників ${ }^{26}$, висловив власне припущення про те, що Богрова могли використати «треті» сили (крім революціонерів і власного бажання Богрова), що були зацікавлені у смерті Столипіна ${ }^{27}$. Зрештою, російські націоналісти взагалі відкидали причетність революціонерів і двірцевих «заколотників» до організації замаху Богрова та висунули іще одну оригінальну версію про те, що, мовляв, російського прем'єр-міністра вбили за рішенням єврейського кагалу, за те, що він, начебто, не погоджувався відпустити 3 
в'язниці М. Бейліса, справа якого тоді розглядалася прокурором Київської судової палати ${ }^{28}$. Подібні думки безпосередніх учасників «справи Столипіна-Богрова», а також іï сучасників, були доволі суб'єктивними, політично заангажованими і вкрай заплутували розгляд реальних обставин справи.

Отже, очевидним було наступне запитання: якщо Богров не був переконаним революціонером, то чому тоді він наважився на вбивство провідного політика Російської імперії? Навряд чи це було вбивством з особистих міркувань, оскільки Столипін і Богров не були навіть знайомими. Очевидно, що спільних інтересів у них також не було. Вбивством із корисливих мотивів (убивство «на замовлення», внаслідок шантажування тощо) цей замах не був, адже, за словами самого Богрова, грошей йому ніколи не бракувало ${ }^{29}$. На психічні захворювання Богров, якщо вірити свідченням його сучасників, начебто не страждав (принаймні, його поведінка до моменту замаху видавалася цілком умотивованою). Політичний чинник у діях Богрова, мабуть, також не грав особливої ролі. Жодна революційна організація не взяла на себе відповідальність за скоєння цього резонансного замаху. Щоправда, Богрова, як відомо, офіційна влада засудила, власне, як політичного злочинцяз а 3-поміж, наприклад, есерів не було одностайності у думках стосовно того, якою повинна бути реакція найбільшої революційної партії Росії на вбивство російського прем'єр-міністра. Зокрема, восени 1911 р. відомий діяч Партії есерів М. І. Ракітніков у своєму листі до одного з лідерів партії В. М. Чернова писав, що есери до скоєння замаху Богрова не причетні, але були свідомі того, що його теракт «безумовно випливав з політичних і революційних мотивів», що, мовляв, політичне значення вбивства Столипіна для есерів було очевидним, адже «Столипін хотів деморалізувати революцію, проте, деморалізував охранку і сам став жертвою власної системи; у цьому перемога революції» ${ }^{31}$. Однак, як зазначав М. І. Ракітніков, єдиної думки 3 приводу «справи Богрова» не було ${ }^{32}$. Проти того, аби дати політичну оцінку діям останнього, виступили провідні діячі Партії есерів М. А. Натансон та I. І. Фондамінський ${ }^{33}$, до позиції яких, мабуть, пристав і В. М. Чернов ${ }^{34}$. Офіційна заява партії стосовно вбивства Столипіна була оприлюднена у жовтні 1911 р., у якій Богрова було визнано «легковажним авантюристом» та «анархістом», котрий здійснив «гідний» вчинок, в організації якого, натомість, есери участі не брали ${ }^{35}$. Зрештою, теорія змови залишається популярною в літературі інтерпретацією обставин замаху, але не зовсім переконливою версією стосовно розуміння мотивації поведінки Богрова. Звісно, що політична фігура відомого реформатора вже мало кого могла задовольнити у 1911 р., у тому числі й самого імператора. Проте необхідність фізичного знищення російського прем'єр-міністра навряд чи входила в плани його численних опонентів і навіть ворогів із-поміж представників вищої царської адміністрації̈

Таким чином, якщо усі інші, відомі нам, мотиви вбивства Столипіна видаються маловірогідними, то, мабуть, є сенс пов'язати їх із національністю вбивці. Як уже зазначалося вище, одним із перших сучасних дослідників, хто звернув увагу на національність Богрова у «справі Столипіна», був В. Любченко, котрий, як нам видається, глибоко проаналізував життєвий шлях «Богрова-єврея», визначив причини його перетворення на «Богрова-революціонера» $\mathrm{i}$ «Богрова-провокатора» ${ }^{37}$ та дійшов того висновку, що «свідомим єврейським патріотом» Богров усе ж таки не був ${ }^{38}$. Однак автор не дав вичерпної відповіді на власне запитання свого дослідження, а саме, «чи рухали вбивцею Столипіна національні мотиви?».

На нашу думку, Богрова можна вважати типовим представником асимільованої частини російського єврейства, який мав непогані перспективи стати успішним адвокатом або підприємцем, якщо взяти до уваги його впливового батька. Проте, як зазначав на допиті М. М. Кулябко, пристрасть Богрова до грошей, ресторанів і жінок стали на заваді реалізації його задумів ${ }^{39}$. Водночас він уперше, мабуть, відчув кризу національної ідентичності, коли йому запропонували охреститися ${ }^{40}$, щоб полегшити собі шлях до соціального успіху в країні, де мільйони євреїв були закуті у правові кайдани смуги осілості. Вартий уваги той факт, що упродовж 1907 - 1913 рр. у Російській імперії спостерігався сплеск масового хрещення євреїв, причому найбільша кількість новонавернених у православну віру єврейських молодиків припадала саме на 1911 рік $^{41}$.

«Життя без життя» - так визначав свій морально-психологічний стан Богров у листі від 24 червня 1909 р. до свого київського товариша ${ }^{42}$, а через рік він уперше висловив своє бажання вбити Столипіна. «Я ненавиджу одну людину, яку ніколи не бачив», - зізнався він у приватній розмові зі своєю товаришкою Б. М. Прілєжаєвою-Барською у Петербурзі навесні 1910 року ${ }^{43}$. На думку Богрова, Столипін був найбільш розумною і талановитою людиною, «але від якої усе зло в 
Росії» ${ }^{44}$. Здійснити свій задум Богров вирішив самостійно, бо жодна революційна організація його не приваблювала, адже, за його словами, він «сам собі був партією»".

Богров, як нам видається, був схильний до суїциду молодою людиною, яка шукала власної смерті, але такої, яка була б освячена героїчним вчинком, бо він, якщо дотримуватися теорії ідентичності Е. Еріксона, втратив власне коріння, власне усвідомлення свого «я», яке було викритим, внаслідок чого людина стає аутсайдером стосовно самої себе. «Від цього моменту, зазначав відомий американський психоаналітик, - людина вже ніколи не буде належати собі та ніколи повністю не уподібнюватиметься “ім". Час від часу вона намагатиметься цілковито стати самою собою, ототожнювати себе зі своїми бунтівними імпульсами; або спробує повністю ототожнити себе з іншими, підкоритися їхнім законам; або ж - і те й друге, в результаті чого вона вже не буде довіряти ні собі, ні іншим» ${ }^{46}$. Про такий морально-психологічний стан, свого часу, влучно зауважив відомий російсько-єврейський анархіст I. С. Гросман (Рощін), коли пригадував, що «в душі у Богрова була осінь, темрява...»" аби наостанок «голосно гримнути дверима» ${ }^{48}$ «Осінь» у душі Богрова, вочевидь, була зумовлена глибокою кризою його російсько-єврейської ідентичності, яку він гостро відчував, коли завітав до відомого діяча Партії есерів Є. Є. Лазарєва та несподівано для останнього заявив про те, що збирається вбити Столипіна з міркувань помсти за «сотні і тисячі роздертих євреїв», що, мовляв, головні винуватці у знущаннях та вбивствах євреїв, зазвичай, залишалися непокараними, а отже, запропонував російським революціонерам визнати майбутній замах, як політичне вбивство 49 . Натомість Є. Є. Лазарєв, як відомо, відмовився, але, водночас, відкидав версію революціонерів про те, що Богров, начебто, був «провокатором» і контраверсію жандармського керівництва у тому, що той, мовляв, був «революціонером». «Залишається припустити, - писав Є. Є. Лазарєв у своєму листі до одного із ветеранів російського революційного руху, відомого публіциста та громадського діяча I. І. Добровольського 22 вересня 1911 р., - що Богров діяв самостійно..., вірогідно - під впливом тих жахіть, які чинилися щодо євреїв у Києві напередодні та 3 приводу візиту високих гостей до Києва» ${ }^{50}$. Є. Є. Лазарєв, мабуть, мав на увазі сумнозвісну «справу Бейліса», що розгорталася у Києві влітку 1911 р., а також масові виселення єврейських родин, які не мали права проживання у Києві, свавілля поліції щодо гнаних євреїв ${ }^{51}$. Навіть П. Г. Курлов, котрий мав уже певний досвід у відносинах із єврейським населенням Мінської губернії, був здивований розмірами хабарництва у структурі київської поліції, представники якої у буквальному сенсі живилися з нерозв'язаного правового статусу місцевих євреїв. Зокрема, зазначав він, лише у Києві можна було спостерігати такі явища, коли євреям забороняли проживання на одному боці вулиці, а в губернському правлінні функціонував особливий відділ 3 «єврейських справ»" ${ }^{52}$ Усе це, мабуть, не могло не дратувати Богрова, котрий мріяв стати поважним адвокатом.

Звісно, що прямих доказів у тому, що «Богров-єврей» скоїв свій замах на грунті помсти самодержавству за його політику антисемітизму, у сучасній історичній літературі, мабуть, немає. Власне їх і не може бути, адже неможливо визначити конкретні мотиви, які штовхають самогубців на здійснення їхнього суїциду. А в тому, що Богров мав подібні мотиви, як уже зазначалося, у його сучасників сумнівів не було. Зокрема, один із лідерів Партії кадетів А. С. Ізгоєв (Ланде) вже через кілька тижнів після київської трагедії не виключав можливого психічного розладу у свідомості убивці Столипіна та спробував довести, що Богров належав до того типу самогубців, які гостро відчували суспільні настрої та сподівалися на суспільне визнання свого останнього вчинку в житті ${ }^{53}$. У цьому контексті цікавими були показники динаміки самогубств 3-поміж євреїв білоруських земель Російської імперії, що їх навела сучасна білоруська дослідниця К. Гатальська, котра, зокрема, зазначала, що до початку світової війни по усій території європейської частини Російської імперії кількість суїцидів 3-поміж єврейського населення неухильно зростала, тоді як аналогічний показник стосовно християн залишався незмінним ${ }^{54}$. На ії думку, позитивна динаміка скоєних суїцидів 3-поміж євреїв пов'язувалася, передусім, із тим, що вони були найбільш чутливими до політичної нестабільності в країні ${ }^{55}$. У тогочасних звітах поліцейських чиновників найпоширенішими мотивами самогубств євреїв фігурували меланхолія, божевілля та ненормальний душевний стан ${ }^{56}$, що загалом засвідчувало про наявність системної кризи ідентичності російських євреїв. На думку Е. Еріксона, «справжня ідентичність залежить від тієї підтримки, яку людина здобуває з колективного відчуття ідентичності, що характеризує значущі для неї соціальні групи: іiї клас, іiї націю, ії культуру. Страх 
втратити ідентичність значною мірою сприятиме суміші справедливості та злочину...» ${ }^{57}$. Київ на початку XX ст., як зазначав сучасний американський історик Н. Меїр, був великим «єврейським» містом пізньоімперської Росії, в якому чимало представників російсько-єврейської інтелігенції зберігали свою політичну лояльність щодо самодержавства, але водночас залишалися євреями, адже «виключно єврейське самовизначення було для них немислимим, непрактичним» ${ }^{58}$. Натомість антисемітизм і націоналізм, що захопили російське суспільство разом із політикою модернізації, вочевидь нагадали російським євреям про їхню «справжню» ідентичність.

Криза російсько-єврейської ідентичності Богрова, як нам видається, була наслідком посилення антисемітизму в Російській імперії (до речі, не лише російського, але й польського ${ }^{59}$ ), особливо на гребні активної участі євреїв у подіях Першої російської революції, з одного боку, та зростання популярності єврейського націоналізму (сіонізму) 3-поміж певної частини російсько-єврейської інтелігенції, з другого. Намагання іï подолати у спосіб скоєння резонансного теракту було альтернативним, примітивним і відчайдушним розв'язанням життєвих проблем, а отже, не може вважатися психопатологією людини.

Однак не зрозуміло, чому Богров обрав своєю майбутньою жертвою обрав саме Столипіна, а не, приміром, Миколу II, якого він без особливих проблем міг убити навіть у тому ж приміщенні театру? Висловлені Богровим побоювання з приводу загрози єврейського погрому в разі загибелі російського імператора навряд чи можна вважати обгрунтованими мотивами, адже Столипін був тоді не менш відомою особистістю в країні, аніж власне Микола II. Очевидно, що Столипіна складно було запідозрити у зайвому лібералізмі з єврейського питання ${ }^{60}$. Наприклад, у 1910 р. він видав циркуляр, за яким була заборонена діяльність єврейських культурно-просвітницьких товариств; у березні 1911 р. відома процентна норма для абітурієнтів з євреїв була поширена й на систему екстернату, в результаті чого, як зазначав відомий російсько-єврейський історик С. М. Дубнов, «величезна маса єврейських дітей, яка опинилася поза школою, була позбавлена також і права на отримання атестата середньої школи» ${ }^{61} .3$ іншого боку, на противагу Миколі II, свідомим антисемітом Столипін, мабуть, ніколи не був ${ }^{62}$. Тобто, у випадку Богрова замах на життя російського імператора більше відповідав би логіці подій. Хоча, звісно, навряд чи Богров узагалі розрізняв політичні погляди обох російських можновладців 3 єврейського питання. Отже, польський історик Л. Базильов мав рацію, коли зауважив із цього приводу, що Столипін, проти життя якого було скоєно 18 замахів $^{63}$, був тією яскравою особистістю, яка легко могла звабити самогубців, подібних до Богрова, котрий, «вочевидь був не зовсім нормальною людиною, а, отже, для нього було достатнім навіть ледь помітної асоціації» ${ }^{64}$. Як нам видається, подібних асоціацій для Богрова напередодні вересневого замаху було чимало.

Зокрема, у серпні 1911 р. несподівано (начебто від дизентерії) помер головний свідок у «справі Бейліса», яка почала «розвалюватися» на очах громадськості ${ }^{65}$. Напередодні візиту до Києва столичних гостей місцевою поліцією запроваджувалися нечувані заходи безпеки, що були принизливими для місцевих євреїв. Наприклад, зривалася вулична реклама з єврейськими прізвищами ${ }^{66}$, а на усіх офіційних церемоніях представників єврейської громадськості, зазвичай, представляли останніми ${ }^{67}$. Навіть урочиста зустріч Миколи II із єврейською депутацією Києва наприкінці серпня, під час якої він прийняв від громадського рабина А. Б. Гуревича сувої святої Тори «на знак глибокого вшанування київськими євреями його величності російського імператора» ${ }^{68}$, виглядала на тлі загальної атмосфери суспільного антисемітизму доволі цинічним політичним заходом. Зрештою, унікальна можливість, як для пересічного єврея та колишнього анархіста, потрапити до приміщення оперного театру, де зібралася майже уся політична еліта Російської імперії на чолі з ії лідером, мабуть, запаморочило свідомість Богрова, який відчув свою особливу місію в історичних процесах країни та власного народу. Зокрема, у своєму виступі на судовому засіданні 9 вересня 1911 р. Богров відверто заявив про те, що залишити приміщення театру без замаху на будьяку державну особу він не збирався, а Столипін виявився найбільш зручною фігурою для цього. «Що я робив, я не усвідомлював. Уперше у мене сталося прояснення, коли мне почали бити...»пригадував на суді Богров ${ }^{69}$. Натомість М. М. Кулябко, який видав Богрову перепустку до театру, був переконаним у тому (а можливо, робив вигляд), що Богров не був євреєм, чим неабияк здивував особистого секретаря Столипіна В. В. Граве, котрий був вражений з того, що досвідчений керівник жандармської служби припустився тієї прикрої помилки, що «допустив до театру, де знаходилась його величність государ імператор, якогось єврея, котрий мав стосунки з революціонерами» ${ }^{70}$. 
Отже, у мотивах замаху на життя голови Ради міністрів Російської імперії Столипіна фактор національності терориста відіграв не останню роль. Звісно, можна погодитися із застереженнями А. С. Ізгоєва 3 приводу того, щоб пояснювати трагедію 1 вересня 1911 р. виключно єврейським походженням Богрова. Відомий російсько-єврейський політичний діяч підкреслював, що в історії тероризму в Російській імперії було чимало не євреїв, і не лише національні мотиви штовхали терористів на скоєння їхніх страшних злочинів. Натомість, як зазначав Л. Базильов, глибокий аналіз мотивації здійснення теракту неодмінно призводить дослідників до розуміння індивідуальних спонук терориста. Якщо у Богрова, вочевидь, не було інших, крім національних, мотивів убивати Столипіна, то, мабуть, немає вагомих підстав заперечувати «єврейський фактор» як своєрідний чинник у цій, безумовно, складній справі. Представник російсько-єврейської інтелігенції Києва, онук відомого російсько-єврейського письменника, Богров опинився, зрештою, у пастці політики асиміляції, що іії намагалося провадити російське самодержавство, адже асиміляція без емансипації загрожувала російським євреям соціальною маргіналізацією, радикалізацією їхньої політичної свідомості. Лави російських революційних партій були насичені молодими радикалами з євреїв, які намагалися помститися режимові за єврейські погроми, антисемітизм і бідність. Прикладів їхньої самопожертви в ролі єврейських героїв російського революційного руху в історії було чимало. Однак Богров не став ідейним революціонером, бо розчарувався у надто виснажливій і не зовсім ефективній, як йому здавалося, революційній боротьбі. Водночас він прагнув суспільного визнання своїх особистих амбіцій, задовольнити які, в статусі єврейського підданого, було, вочевидь, не просто. Публічне самогубство стало для нього трагічним фіналом у його болісних процесах пошуку шляхів подолання кризи ідентичності. Парадоксальність ситуації у тому, що йому все ж таки вдалося досягти своєї мети, адже таємницю вбивства Столипіна він назавжди пов'язав із власним ім'ям.

1 П. А. Стольпин. Жизнь за Отечество, 1862 - 1911 [Р. A. Stolypin. Life for the Fatherland, 1862 - 1911 ], Г. П. Сидоровнин, Москва, Терра-Книжный клуб, 2002, с. 555 - 556.

2 В. П. Даниленко, Вбивство Столипіна: офіиійна версія $і$ архівні документи [The assassination of Stolypin: the official version and archival documents], in «Архіви України», 2011, №2-3 (273), с. 197.

3 Тайна убийства Стольлина [The Secret of Stolypin's Murder], П. А. Пожигайло, И. И. Демидов, С. В. Мироненко, В. В. Шелохаев, Москва, РОССПЭН, 2003, 736 с.

4 Предисловие [Foreword], in «Тайна убийства Столыпина», П. А. Пожигайло, И. И. Демидов, С. В. Мироненко, В. В. Шелохаев, Москва, РОССПЭН, 2003, с. 29.

5 П. Н. Зырянов, Петр Аркадьевич Стольпин [Petr Arkadevich Stolypin], in «Россия на рубеже веков: исторические портреты», Москва, Политиздат, 1991, с. 76.

6 П. Н. Зырянов, Петр Аркадьевич Стольпин, с. 75.

7 П. Н. Зырянов, Петр Аркадьевич Стольпиин, с. 77.

8 Д. В. Табачник, В. Н. Воронин, Крёстный путь Петра Стольпина [The path of Peter Stolypin], Харьков, Фолио, 2012, 536 с.

9 С. Е. Резник, Вместе или врозь? Судьба евреев в России. Заметки на полях дилогии А. И. Солженицина [Together or apart? The fate of the Jews in Russia. Notes on the fields of the A. I. Solzhenitsyn's dilogy], Москва, Захаров, 2005, 704 с..

10 Д. В. Табачник, В. Н. Воронин, Крёстньй путь Петра Стольпина, с. 425.

11 А. И. Солженицын, Двести лет вместе (1795 - 1995) [Two hundred years together (1795 - 1995)], Ч. I, Москва, Русский путь, 2001, 512 с.

12 С. Е. Резник, Вместе или врозь? Судьба евреев в России. Заметки на полях дилогии А. И. Солженицина, c. 277.

13 С. Е. Резник, Вместе или врозь? Судьба евреев в России. Заметки на полях дилогии А. И. Солженицина, c. 299.

14 С. Рыбас, Л. Тараканова, Жизнь и смерть Петра Стольпина [Life and death of Peter Stolypin], in «Смена», 1991, №6, с. 81 .

15 Предисловие, с. 44.

16 Предисловие, с. 45.

17 Предисловие, с. 46.

18 Політичний терор і тероризм в Украӥні. ХІХ-XX cm. Iсторичні нариси [Political Terror and Terrorism in Ukraine. Nineteenth and twentieth centuries. Historical Essays], Д. В. Архієрейський, О. Г. Бажан, Т. В. Бикова, В. А. Смолій, Київ, 2002, Наукова думка, с. 105 - 120. 
19 В. Любченко, «Я боролся за счастье и благо еврейского народа» (Двигали ли убийцей Стольпина национальные мотивы?) ["I fought for the happiness and good of the Jewish people" (Have Stolypin's killers moved national motives?)], in «Тирош - труды по иудаике», Вып. 5, Сборник статей, Сep. «Judaica Rossica», Москва, 2001, с. 207 - 216.

20 Політичний терор і тероризм в Украйні. ХІХ-XX cm. Історичні нариси, с.111.

21 Політичний терор і тероризм в Україні. ХІХ-XX сm. Історичні нариси, с.107.

22 В. Любченко, «Я боролся за счастье и благо еврейского народа» (Двигали ли убийцей Стольпина национальные мотивы?), с. 215.

23 В. Хитерер, Царь и евреи. Визит Николая II в Киев в 1911 г. [The Tsar and the Jews. Visit of Nicholas II to Kiev in 1911], in «Еврейский мир Украины», at http://www.ju.org.ua/ru/publicism/800.html.

24 Предисловие, с. 31.

25 Г. Сандомирский, По поводу старого спора [Concerning the old dispute], in «Каторга и ссылка. Историко-революционный вестник», 1926, №2 (23), с. 24 - 27.

26 Г. Сандомирский, По поводу старого спора, с. 28.

27 П. Курлов, Конеи русского ичаризма. Воспоминания бывшего командира корпуса жандармов [Тhе end of Russian tsarism. Memoirs of the former commander of the corps of gendarmes], Москва, Государственное издательство, 1923, с. 159.

28 С. Степанов, Чёрная сотня [The Black Hundred], Москва, Эксмо, Яуза, 2005, с. 373.

29 Протокол допроса Д. Г. Богрова, 2 сентября 1911 г. [Protocol of interrogation D. G. Bogrov, September 2, 1911], in «Тайна убийства Столыпина», П. А. Пожигайло, И. И. Демидов, С. В. Мироненко, В. В. Шелохаев, Москва, РОССПЭН, 2003, с. 56.

30 Приговор Киевского военно-окружного суда, 9 сентября 1911 г. [The verdict of the Kiev Military District Court, September 9, 1911], in «Тайна убийства Столыпина», П. А. Пожигайло, И. И. Демидов, С. В. Мироненко, В. В. Шелохаев, Москва, РОССПЭН, 2003, с. 91.

31 К. Н. Морозов, Партия соичиалистов-революичонеров в 1907-1914 г2. [Party of Socialist-Revolutionaries in 1907 - 1914], Москва, РОССПЭН, 1998, с. 583.

32 К. Н. Морозов, Партия соичалистов-революционеров в 1907 - 1914 г2., с. 587.

33 К. Н. Морозов, Партия соииалистов-револючионеров в 1907 - 1914 г2., с. 583.

34 К. Н. Морозов, Партия социалистов-революционеров в 1907 - 1914 г2., с. 584.

35 Отклики социилистов [Socialists’ responses], in «Убийство Столыпина. Свидетельства и документы», А. Серебренников, Нью-Йорк, Телекс, 1989, с. 25.

36 Г. П. Сидоровнин, Конфликт П. А. Столыпина с Николаем II: пролегомены к гибели монархии [Conflict of P. A. Stolypin with Nicholas II: Prolegomena to the death of the monarchy], in «Учёные записки Орловского государственного университета», 2015, №2 (65), с. 27 - 31.

37 В. Любченко, «Я боролся за счастье и благо еврейского народа» (Двигали ли убийцей Стольпина национальные мотивы?), с. 207 - 209.

38 В. Любченко, «Я боролся за счастье и благо еврейского народа» (Двигали ли убийцей Стольпина национальные мотивы?), с. 214.

39 Протокол допроса подполковника Н. Н. Кулябко, 24 сентября 1911 г. [Protocol of interrogation of Lieutenant Colonel N. N. Kulyabko, September 24, 1911], in «Тайна убийства Столыпина», П. А. Пожигайло, И. И. Демидов, С. В. Мироненко, В. В. Шелохаев, Москва, РОССПЭН, 2003, с. 139 - 145.

40 А. Мушин, Богров - до 25 августа 1911 г. [Bogrov - until August 25, 1911], in «Убийство Столыпина. Свидетельства и документы», А. Серебренников, Нью-Йорк, 1989, с. 120.

41 В. Е. Кельнер, Миссионер истории: Жизнь и труды Семёна Марковича Дубнова [Missionary History: Life and Works of Semyon Markovich Dubnov], Санкт-Петербург, Мир, 2008, с. 441.

42 А. Мушин, Богров - до 25 августа 1911 г. с. 111.

43 Б. Прилежаева-Барская [В. Prilezhaeva-Barskaja], in «Убийство Столыпина. Свидетельства и документы», А. Серебренников, Нью-Йорк, Телекс, 1989, с. 94.

44 Б. Прилежсаева-Барская, с. 94.

45 Б. Прилежаева-Барская, с. 92.

46 Философские сюжеты Эрика Эриксона: переводы работ американского психоаналитика [Philosophical subjects of Eric Erickson: translations of the works of the American psychoanalyst], П. С. Гуревич, Москва, Канон+ РООИ «Реабилитация», 2017, с. 272.

47 И. Гроссман-Рощчин [I. Grossman-Roshhin], in «Убийство Столыпина. Свидетельства и документы», А. Серебренников, Нью-Йорк, Телекс, 1989, с. 129.

48 И. Гроссман-Рошин, с. 130.

49 Е. Лазарев, Первое свидание с Богровым [The First Date with Bogrov], in «Убийство Столыпина. Свидетельства и документы», А. Серебренников, Нью-Йорк, Телекс, 1989, с. 142 - 150. 
50 Выписка из письма Е. Е. Лазарева, Кларан, Швейцария-доктору И. И. Добровольскому, Петербург, 22 сентября 1911 г. [Extract from the letter of E. E. Lazareva, Claren, Switzerland - to Dr. I. I. Dobrovolsky, Petersburg, September 22, 1911], in «Тайна убийства Столыпина», П. А. Пожигайло, И. И. Демидов, С. В. Мироненко, В. В. Шелохаев, Москва, РОССПЭН, 2003, с. 681.

51 Н. Меїр, Свреї в Києві, 1859 - 1914 [Jews in Kiev, 1859 - 1914], Київ, Дух і Літера, 2016, с. 178.

52 П. Курлов, Конец русского ичаризма. Воспоминания бывщего командира корпуса жандармов [Тһе end of Russian tsarism. Memoirs of the former commander of the corps of gendarmes], Москва, Государственное издательство, 1923, с. 69.

53 А. С. Изгоев, По поводу убийства П. А. Стольпина. В России и за границей. Обзоры и заметки [Аbout the murder of P. A. Stolypin. In Russia and abroad. Reviews and notes], in «Русская мысль», 1911, № 10, с. 5.

54 К. Гатальская, Самоубийства среди евреев на белорусских землях Российской империи в период 18601914 г2. (по материалам Национального исторического архива Республики Беларусь) [Suicide among Jews in the Belarusian lands of the Russian Empire in the period 1860-1914 (based on the materials of the National Historical Archive of the Republic of Belarus)], in «Проблемы еврейской истории. Часть I. Материалы научных конференций Центра «Сэфер» по иудаике 2007 года», Москва, Книжники, 2008, с. 298.

55 К. Гатальская, Самоубийства среди евреев на белорусских землях Российской империи в период 1860 1914 гz. (по материалам Наџионального исторического архива Республики Беларусь), с. 298.

56 К. Гатальская, Самоубийства среди евреев на белорусских землях Российской империи в период 18601914 г2. (по материалам Национального исторического архива Республики Беларусь), с. 295.

57 Философские сюжеты Эрика Эриксона: переводы работ американского психоаналитика, с. 267.

58 Н. Меїр, Свреї в Києві, 1859 - 1914 [Jews in Kiev, 1859 - 1914], Київ, Дух і Літера, 2016, с. 29.

59 С. М. Дубнов, Евреи в России и Западной Европе в эпоху антисемитской реакиии. Кн. II. Евреи в России в ичарствование Николая II. (1894-1914) [Jews in Russia and Western Europe in the era of anti-Semitic reaction. Book II. Jews in Russia in the reign of Nicholas II (1894-1914)], Москва, Петроград, 1923, Издательство Л. Д. Френкель, с. 98.

60 П. Курлов, Конеи русского изаризма. Воспоминания бывшего командира корпуса жандармов [Тһе end of Russian tsarism. Memoirs of the former commander of the corps of gendarmes], Москва, Государственное издательство, 1923, с. 114.

61 С. М. Дубнов, Евреи в России и Западной Европе в эпоху антисемитской реакции. Кн. II. Евреи в России в царствование Николая II. (1894-1914), с. 94 - 95.

62 О. М. Машкін, П. А. Столипін та Украӥна [Р. A. Stolypin and Ukraine], in «Український історичний журнал», 2012, №2, с. 85 .

63 О. М. Машкін, П. А. Столипін та Украӥна, с. 96.

64 Л. Базылёв, Загадка 1 сентября 1911 г. [Riddle on September 1, 1911], in «Вопросы истории», 1975, №7, c. 127 .

65 С. Степанов, Чёрная сотня, с. 370.

66 Центральний державний історичний архів України у м. Київ [ЦДІАК України], ф. 275 Киевское охранное отделение, оп. 1, спр. 2527 Дело о разработке писем, полученных агентурным путём и политической проверке разных лии, 9 мая - 26 октября 1911 г., арк. 233.

67 П. Курлов, Конец русского изаризма. Воспоминания бывщего командира корпуса жандармов [Тһе end of Russian tsarism. Memoirs of the former commander of the corps of gendarmes], Москва, Государственное издательство, 1923, с. 51.

68 Депутация от еврейского населения г. Киева [Deposition from the Jewish population of Kiev], in «Киевлянин», 1911, №241, с. 2 - 3.

69 Запись выступления Д. Г. Богрова в Киевском военно-окружном суде, 9 сентября 1911 г. [Record of the speech of D. G. Bogrov in the Kiev Military District Court, September 9, 1911], in «Тайна убийства Столыпина», П. А. Пожигайло, И. И. Демидов, С. В. Мироненко, В. В. Шелохаев, Москва, РОССПЭН, 2003, с. 88.

70 Показания В. В. Граве - личного секретаря П. А. Стольпина [Indications of V. V. Grave - personal secretary P. A. Stolypin], in «Тайна убийства Столыпина», П. А. Пожигайло, И. И. Демидов, С. В. Мироненко, В. В. Шелохаев, Москва, РОССПЭН, 2003, с. 101.

\section{Reference}

1. P. A. Stolypin. Zhizn’ za Otechestvo, 1862 - 1911, G. P. Sidorovnin, Moskva, Terra-Knizhnyj klub, 2002 , s. $555-556$.

2. V. P. Danylenko, Vbyvstvo Stolypina: oficijna versija i arhivni dokumenty, in «Arhivy Ukrai’ny», 2011, №2-3 (273), s. 197.

3. Tajna ubijstva Stolypina, P. A. Pozhigajlo, I. I. Demidov, S. V. Mironenko, V. V. Shelohaev, Moskva, ROSSPJeN, 2003, $736 \mathrm{~s}$. 
4. Predislovie, in «Tajna ubijstva Stolypina», P. A. Pozhigajlo, I. I. Demidov, S. V. Mironenko, V. V. Shelohaev, Moskva, ROSSPJeN, 2003, s. 29.

5. P. N. Zyrjanov, Petr Arkad'evich Stolypin, in «Rossija na rubezhe vekov: istoricheskie portrety», Moskva, Politizdat, 1991, s. 76.

6. P. N. Zyrjanov, Petr Arkad'evich Stolypin, s. 75.

7. P. N. Zyrjanov, Petr Arkad'evich Stolypin, s. 77.

8. D. V. Tabachnik, V. N. Voronin, Krjostnyj put' Petra Stolypina, Har'kov, Folio, 2012, 536 s.

9. S. E. Reznik, Vmeste ili vroz'? Sud'ba evreev v Rossii. Zametki na poljah dilogii A. I. Solzhenicina, Moskva, Zaharov, 2005, $704 \mathrm{~s}$.

10. D. V. Tabachnik, V. N. Voronin, Krjostnyj put' Petra Stolypina, s. 425.

11. A. I. Solzhenicyn, Dvesti let vmeste (1795 - 1995), Ch. I, Moskva, Russkij put', 2001, 512 s.

12. S. E. Reznik, Vmeste ili vroz'? Sud'ba evreev v Rossii. Zametki na poljah dilogii A. I. Solzhenicina, s. 277.

13. S. E. Reznik, Vmeste ili vroz'? Sud'ba evreev v Rossii. Zametki na poljah dilogii A. I. Solzhenicina, s. 299.

14. S. Rybas, L. Tarakanova, Zhizn’ i smert’ Petra Stolypina, in «Smena», 1991, №6, s. 81.

15. Predislovie, s. 44.

16. Predislovie, s. 45.

17. Predislovie, s. 46.

18. Politychnyj teror i teroryzm v Ukrai’ni. XIX - XX st. Istorychni narysy, D. V. Arhijerejs'kyj, O. G. Bazhan, T. V. Bykova, V. A. Smolij, Kyi'v, 2002, Naukova dumka, s. 105 - 120.

19. V. Ljubchenko, «Ja borolsja za schast'e i blago evrejskogo naroda» (Dvigali li ubijcej Stolypina nacional'nye motivy?), in «Tirosh - trudy po iudaike», Vyp. 5, Sbornik statej, Ser. «Judaica Rossica», Moskva, 2001, s. $207-216$.

20. Politychnyj teror i teroryzm v Ukrai’ni. XIX - XX st. Istorychni narysy, s. 111.

21. Politychnyj teror i teroryzm v Ukrai'ni. XIX - XX st. Istorychni narysy, s. 107.

22. V. Ljubchenko, «Ja borolsja za schast'e i blago evrejskogo naroda» (Dvigali li ubijcej Stolypina nacional'nye motivy?), s. 215.

23. V. Hiterer, Car' i evrei. Vizit Nikolaja II v Kiev v 1911 g., in «Evrejskij mir Ukrainy», at http://www.ju.org.ua/ $\mathrm{ru} /$ publicism/800.html.

24. Predislovie, s. 31.

25. G. Sandomirskij, Po povodu starogo spora, in «Katorga i ssylka. Istoriko-revoljucionnyj vestnik», 1926, №2 (23), s. $24-27$.

26. G. Sandomirskij, Po povodu starogo spora, s. 28.

27. P. Kurlov, Konec russkogo carizma. Vospominanija byvshego komandira korpusa zhandarmov, Moskva, Gosudarstvennoe izdatel'stvo, 1923, s. 159.

28. S. Stepanov, Chjornaja sotnja, Moskva, Jeksmo, Jauza, 2005, s. 373.

29. Protokol doprosa D. G. Bogrova, 2 sentjabrja 1911 g., in «Tajna ubijstva Stolypina», P. A. Pozhigajlo, I. I. Demidov, S. V. Mironenko, V. V. Shelohaev, Moskva, ROSSPJeN, 2003, s. 56.

30. Prigovor Kievskogo voenno-okruzhnogo suda, 9 sentjabrja 1911 g., in «Tajna ubijstva Stolypina», P. A. Pozhigajlo, I. I. Demidov, S. V. Mironenko, V. V. Shelohaev, Moskva, ROSSPJeN, 2003, s. 91.

31. K. N. Morozov, Partija socialistov-revoljucionerov v 1907 - 1914 gg., Moskva, ROSSPJeN, 1998 , s. 583.

32. K. N. Morozov, Partija socialistov-revoljucionerov v 1907 - 1914 gg., s. 587.

33. K. N. Morozov, Partija socialistov-revoljucionerov v 1907 - 1914 gg., s. 583.

34. K. N. Morozov, Partija socialistov-revoljucionerov v 1907 - 1914 gg., s. 584.

35. Otkliki socialistov, in «Ubijstvo Stolypina. Svidetel'stva i dokumenty», A. Serebrennikov, N'ju-Jork, Teleks, 1989 , s. 25.

36. G. P. Sidorovnin, Konflikt P. A. Stolypina s Nikolaem II: prolegomeny k gibeli monarhii, in «Uchjonye zapiski Orlovskogo gosudarstvennogo universiteta», 2015, №2 (65), s. 27 - 31.

37. V. Ljubchenko, «Ja borolsja za schast'e i blago evrejskogo naroda» (Dvigali li ubijcej Stolypina nacional'nye motivy?), s. $207-209$.

38. V. Ljubchenko, «Ja borolsja za schast'e i blago evrejskogo naroda» (Dvigali li ubijcej Stolypina nacional'nye motivy?), s. 214.

39. Protokol doprosa podpolkovnika N. N. Kuljabko, 24 sentjabrja 1911 g., in «Tajna ubijstva Stolypina», P. A. Pozhigajlo, I. I. Demidov, S. V. Mironenko, V. V. Shelohaev, Moskva, ROSSPJeN, 2003, s. 139 - 145.

40. A. Mushin, Bogrov - do 25 avgusta 1911 g., in «Ubijstvo Stolypina. Svidetel’stva i dokumenty», A. Serebrennikov, N'ju-Jork, 1989, s. 120.

41. V. E. Kel'ner, Missioner istorii: Zhizn' i trudy Semjona Markovicha Dubnova, Sankt-Peterburg, Mir, 2008, s. 441

42. A. Mushin, Bogrov - do 25 avgusta 1911 g., s. 111. 
43. B. Prilezhaeva-Barskaja, in «Ubijstvo Stolypina. Svidetel'stva i dokumenty», A. Serebrennikov, N'ju-Jork, Teleks, 1989, s. 94.

44. B. Prilezhaeva-Barskaja, s. 94.

45. B. Prilezhaeva-Barskaja, s. 92.

46. Filosofskie sjuzhety Jerika Jeriksona: perevody rabot amerikanskogo psihoanalitika, P. S. Gurevich, Moskva, Kanon+ ROOI «Reabilitacija», 2017, s. 272.

47. I. Grossman-Roshhin, in «Ubijstvo Stolypina. Svidetel'stva i dokumenty», A. Serebrennikov, N'ju-Jork, Teleks, 1989, s. 129.

48. I. Grossman-Roshhin, s. 130.

49. E. Lazarev, Pervoe svidanie s Bogrovym, in «Ubijstvo Stolypina. Svidetel'stva i dokumenty», A. Serebrennikov, N'ju-Jork, Teleks, 1989, s. $142-150$.

50. Vypiska iz pis'ma E. E. Lazareva, Klaran, Shvejcarija - doktoru I. I. Dobrovol'skomu, Peterburg, 22 sentjabrja 1911 g., in «Tajna ubijstva Stolypina», P. A. Pozhigajlo, I. I. Demidov, S. V. Mironenko, V. V. Shelohaev, Moskva, ROSSPJeN, 2003, s. 681.

51. N. Mei’r, Jevrei’ v Kyjevi, 1859 - 1914, Kyi’v, Duh i Litera, 2016, s. 178.

52. P. Kurlov, Konec russkogo carizma. Vospominanija byvshego komandira korpusa zhandarmov, s. 69.

53. A. S. Izgoev, Po povodu ubijstva P. A. Stolypina. V Rossii i za granicej. Obzory i zametki, in «Russkaja mysl'», 1911, № 10, s. 5.

54. K. Gatal'skaja, Samoubijstva sredi evreev na belorusskih zemljah Rossijskoj imperii v period 1860-1914 gg. (po materialam Nacional'nogo istoricheskogo arhiva Respubliki Belarus'), in «Problemy evrejskoj istorii. Chast' I. Materialy nauchnyh konferencij Centra «Sjefer» po iudaike 2007 goda», Moskva, Knizhniki, 2008, s. 298.

55. K. Gatal'skaja, Samoubijstva sredi evreev na belorusskih zemljah Rossijskoj imperii v period 1860-1914 gg. (po materialam Nacional'nogo istoricheskogo arhiva Respubliki Belarus'), s. 298.

56. K. Gatal'skaja, Samoubijstva sredi evreev na belorusskih zemljah Rossijskoj imperii v period 1860-1914 gg. (po materialam Nacional'nogo istoricheskogo arhiva Respubliki Belarus'), s. 295.

57. Filosofskie sjuzhety Jerika Jeriksona: perevody rabot amerikanskogo psihoanalitika, s. 267.

58. N. Mei'r, Jevrei' v Kyjevi, 1859 - 1914, s. 29.

59. S. M. Dubnov, Evrei v Rossii i Zapadnoj Evrope v jepohu antisemitskoj reakcii. Kn. II. Evrei v Rossii v carstvovanie Nikolaja II. (1894-1914), Moskva, Petrograd, 1923, Izdatel'stvo L. D. Frenkel', s. 98.

60. P. Kurlov, Konec russkogo carizma. Vospominanija byvshego komandira korpusa zhandarmov, s. 114.

61. S. M. Dubnov, Evrei v Rossii i Zapadnoj Evrope v jepohu antisemitskoj reakcii. Kn. II. Evrei v Rossii v carstvovanie Nikolaja II. (1894-1914), s. $94-95$.

62. O. M. Mashkin, P. A. Stolypin ta Ukrai’na, in «Ukrai’ns’kyj istorychnyj zhurnal», 2012, №2, s. 85.

63. O. M. Mashkin, P. A. Stolypin ta Ukrai’na, s. 96.

64. L. Bazyljov, Zagadka 1 sentjabrja 1911 g., in «Voprosy istorii», 1975, №7, s. 127.

65. S. Stepanov, Chjornaja sotnja, s. 370.

66. Central'nyj derzhavnyj istorychnyj arhiv Ukrai'ny u m. Kyi’v, f. 275 Kievskoe ohrannoe otdelenie, op. 1, spr. 2527 Delo o razrabotke pisem, poluchennyh agenturnym putjom i politicheskoj proverke raznyh lic, 9 maja - 26 oktjabrja 1911 g., ark. 233.

67. P. Kurlov, Konec russkogo carizma. Vospominanija byvshego komandira korpusa zhandarmov, s. 51.

68. Deputacija ot evrejskogo naselenija g. Kieva, in «Kievljanin», 1911, №241, s. 2 - 3.

69. Zapis’ vystuplenija D. G. Bogrova v Kievskom voenno-okruzhnom sude, 9 sentjabrja 1911 g., in «Tajna ubijstva Stolypina», P. A. Pozhigajlo, I. I. Demidov, S. V. Mironenko, V. V. Shelohaev, Moskva, ROSSPJeN, 2003 , s. 88.

70. Pokazanija V. V. Grave - lichnogo sekretarja P. A. Stolypina, in «Tajna ubijstva Stolypina», P. A. Pozhigajlo, I. I. Demidov, S. V. Mironenko, V. V. Shelohaev, Moskva, ROSSPJeN, 2003, s. 101 